BARTOSZ WYPYCH

Instytut Politologii UMK

\title{
Freak w okowach polityki
}

Doziomów analizy relacji, jakie mają miejsce pomiędzy literaturą a sferą polityki, można zapewne wymienić wiele. Najbardziej oczywista wydawać się może metoda analizy wewnętrznej oraz zewnętrznej dzieła literackiego. Nigdy nie powstaje ono w próżni. Zawsze zatem możliwa staje się taka analiza, której głównym problemem są warunki polityczne, w jakich przyszło tworzyć autorowi dzieła. Stąd, poszukiwanie wątków politycznych nie jest pozbawione sensu nawet wówczas, gdy mamy do czynienia z literaturą spod znaku science-fiction, fantasy czy cyber-punk. Co więcej, w myśl koncepcji poststrukturalistycznych, nawet wówczas, gdy nie uda nam się odnaleźć żadnych powiązań między konkretnym dziełem literackim a sferą polityki, nie oznacza to, że nie ma ich w ogóle. Sens dzieła nie jest mu bowiem nadany raz na zawsze przez jego autora, ale powstaje za każdym razem, kiedy odbiorca odczytuje komunikat, jaki stanowi konkretna książka. Dlatego też, to właśnie czytelnik staje się ostateczną instancją rozstrzygającą o politycznym charakterze danego dzieła.

Dużo ciekawsza, w mojej ocenie, wydaje się jednak próba swoistej generalizacji i wyjścia poza zwykłą analizę wewnętrzną, a nawet zewnętrzną konkretnego tytułu. Znacznie bardziej kusząca jest próba odniesienia wyników analizy do tendencji, z jakimi mamy do czynienia w kulturze, w jej wymiarze społecznym i politycznym. Dlatego też, w tekście tym, chciałbym się skupić na poszukiwaniu wzorca bohatera współczesnej literatury polskiej i pokazać, w jakim stopniu możliwe jest przypisanie go do kształtu polityki, który wyłania się na skutek przemian związanych z emergencją szeroko ro- 
zumianego społeczeństwa ponowoczesnego i rządzącą nim kulturą indywidualizmu.

Już na wstępie jednak pragnę zaznaczyć, że prezentowane przeze mnie stanowisko może wydać się komuś wyjątkowo nieobiektywne. Jako ilustrację pewnego założenia teoretycznego wybrałem bowiem konkretne dzieła literackie (z prozy oraz dramatu), które w ostatnich latach zyskały sobie uznanie i popularność wśród polskich odbiorców ${ }^{1}$. Materiał badawczy jest jednak tak ogromny - wszak rynek wydawniczy w Polsce wydaje się przeżywać okres „rozkwitu” - że możliwa jest sytuacja, w której ktoś będzie w stanie przywołać szereg innych dzieł współczesnej literatury polskiej, pozbawiając moje stanowisko roszczeń do jakichkolwiek uogólnień.

\section{Polityka życia. Polityka tożsamości}

Pisząc wyżej o pewnych trendach, jakie można wyróżnić we współczesnej polityce, mam przede wszystkim na myśli politykę życia i politykę tożsamości. Pokrótce wypadałoby zatem wyjaśnić, co kryje się pod tymi zbitkami pojęciowymi, by móc później rozstrzygnąć, w jaki rodzaj polityki najlepiej wpisuje się współczesny bohater literacki. Polityka życia to polityka, która rozgrywa się na poziomie indywidualnych wyborów tożsamościowych wszelkiego rodzaju: od rodzaju noszonej fryzury, po gatunek kawy czy herbaty, jaką zwykliśmy pić. Obecnie, jak dowodzi Jean Baudrillard, nie ma takiej opcji, by być wolnym od przymusu wyboru², więc repertuar zachowań politycznych pozostaje potencjalnie nieograniczony. Słusznie zatem podkreśla Anthony Giddens, że polityka życia jest polityką decyzji życiowych. Zwraca on jednak uwagę, że: „Przede wszystkim są to decyzje dotyczące samej tożsamości jednostki. [...] tożsamość jest dziś dokonaniem refleksyjnym. Narrację tożsamościową trzeba kształtować, modyfikować i refleksyjnie podtrzymywać w kontekście gwałtownych zmian zachodzących w życiu społecznym w skali lokalnej i globalnej. Jednostka musi tak godzić na rozmaite sposoby zapośredniczone informacje ze sprawami lokalnymi, by połączyć $\mathrm{w}$ spójną w miarę całość swoje projekty na przyszłość i przyszłe doświadczenia"3.

M.in.: M. Cegielski, Masala, Warszawa 2002; D. Masłowska, Wojna polsko ruska pod flaga białoczerwona, Warszawa 2003; J. Nasierowski, Nie moje życie, Warszawa 2002; Made in Poland. Dziewięć sztuk teatralnych z Polski w wyborze Romana Pawłowskiego, red. H. Sułek, Kraków 2006; Pokolenie porno i inne niesmaczne utwory teatralne. Antologia najnowszego dramatu polskiego $w$ wyborze Romana Pawłowskiego, red. tenże, Kraków 2004. Analiza obejmowała jednak szerszy wybór współczesnej literatury polskiej.

Zob. J. Baudrillard, The System of Objects, London-New York 2005, s. 151.

A. Giddens, Nowoczesność i tożsamość, Warszawa 2007, s. 293. 
Polityka życia bazuje na układaniu gotowych, dostępnych cegiełek biografii i ich późniejszym przetwarzaniu. Stąd, jest ona doskonałym odzwierciedleniem praw kultury indywidualizmu. Omawiając kwestię kształtowania osobowości, nie można oczywiście zapomnieć o roli, jaką odgrywają $\mathrm{w}$ tym procesie podmioty zinstytucjonalizowane. Ulrich Beck, przedstawiając swój ahistoryczny model indywidualizacji, podkreśla, że elementy, które się na nią składają: uwolnienie, utrata stabilności oraz rodzaj kontroli; powinny być rozpatrywane zarówno $\mathrm{z}$ uwzględnieniem położenia życiowego jako czynnika obiektywnego, jak również z uwzględnieniem świadomości/tożsamości jako czynnika subiektywnego. Współcześnie, mamy do czynienia ze swoistym paradoksem, który powoduje, że biografia kształtowana jest $\mathrm{z}$ jednej strony poprzez swobodnie podejmowane decyzje, z drugiej natomiast poprzez zinstytucjonalizowane wzory. „Oznacza to - jak pisze Beck że dzięki danym instytucjonalnym i tym wynikającym z losów powstają cegiełki biograficznych możliwości kombinacyjnych. W przejściu od «biografii normalnej» do «biografii z wyboru» [...] kształtuje się pełen konfliktów, w historii nie praktykowany typ «biografii zrób-to-sam» [...]"4. Tym niemniej, w perspektywie temporalnej „horyzonty czasowe percepcji życia coraz bardziej się zawężają, aż wreszcie, w przypadku granicznym, «historia kurczy się do (wiecznej) teraźniejszości» i wszystko obraca się wokół osi własnego ja, własnego życia"s.

Tożsamość jest, rzecz jasna, także głównym przedmiotem zainteresowania drugiego z wymienionych tutaj rodzajów polityki. Jak piszą Steven Best oraz Douglas Kellner: „«Polityka tożsamości» odnosi się do polityki, w ramach której jednostki konstruują swoje kulturowe i polityczne tożsamości poprzez zaangażowanie się w walkę lub działalność stowarzyszeń wpierających interesy grup, z którymi jednostki te się identyfikują"6.

Tożsamość jako przedmiot zainteresowania polityki tożsamości działa na zasadzie gotowego wzorca. Jednostka przejmuje go od grupy, w ramach której funkcjonuje. Zaznaczyć trzeba jednak, że wymóg przynależności do grupy nie jest wymogiem koniecznym. O ile zatem osobowość podmiotu polityki życia funkcjonuje na zasadzie, charakteryzowanej przez Deleuze'a i Guattari'ego, osobowości nomadycznej, o tyle podmiot polityki tożsamości - w obrębie jasno wytyczonego systemu normatywno-aksjologicznego.

$4 \quad$ U. Beck, Społeczeństwo ryzyka. W drodze do innej nowoczesności, przeł. S. Cieśla, Warszawa 2002, s. 202.

Tamże, s. 202.

6 S. Best, D. Kellner, Polityka postmodernistyczna i bitwa o przyszłość, przeł. K. Urbańska, B. Wypych, „Dialogi Polityczne” 2008, nr 10, s. 323. 
„Nomada nie zajmuje terytorium, nie zakreśla granic ani też nie wyznacza centrum - on terytoria opuszcza, w procesie stałego przemieszczania, co znaczy [...] że każdy moment reterytorializacji jest zarazem deterytorializacją, i to właśnie różni nomadę od wychodźcy czy osiedleńca. Wędrówka nomady nie jest drogą-linią, mającą początek i końcowy cel, jego wędrowanie to wypełnianie przestrzeni otwartej"7.

Tożsamość w ramach polityki życia jawi się, w odróżnieniu od polityki tożsamości, jako proces bez wyraźnego końca. Celem nie jest tu zatem swoista osobowościowa konstytucja, lecz raczej samo kształtowanie, nieustanny wybór pomiędzy alternatywami występującymi na wszelkich poziomach egzystencji jednostki w społeczeństwie. I choć stwarzanie własnej tożsamości musi być, co podkreślał Giddens, projektem świadomym, refleksyjnym, to ostateczny wynik nigdy nie może zostać przewidziany. Zygmunt Bauman, porównując tożsamość do układanki, pisze: „Owszem, mamy na stole przed sobą mnóstwo kawałeczków i chcemy z nich ułożyć sensowną całość. Jednak obraz, który powinien się wyłonić na końcu pracy, nie jest z góry dany. Nie wiadomo więc na pewno, czy mamy wszystkie potrzebne kawałeczki, czy wybieramy właściwie z tego, co leży na stole, i czy ułożymy końcowy wzór"8.

Wydaje się, że politykę tożsamości można umiejscowić pomiędzy polityką emancypacji, od której różni się jedynie zmianą kategorii społecznej będącej podstawą do określenia własnego ,ja”, a postmodernistyczną wiarą w różnicę. Oczywiście, zarówno polityka życia jak i polityka tożsamości wyłaniają się z polityki emancypacji. Niemniej jednak, kwestionują one główną kategorię, jaka się za nią kryje, czyli uniwersalizm.

„Podmiot polityki emancypacji to podmiot transcendentalny - «każdy człowiek», «wszyscy obywatele» i «każdy bez względu na rasę, płeć, wiek, przynależność etniczną i wyznanie». Roszczenia związane z «prawem do tożsamości» kładą kres wierze w uniwersalnego człowieka. Podmiot polityki życia domaga się uznania, że realizuje się i żyje w różnicy [...], dlatego przysługujące mu prawa muszą być skonkretyzowane, czyli realizowane właśnie ze względu na wszystkie te różnice, które usiłowano wyeliminować w figurze uniwersalnego człowieka"'.

Po krótkim przedstawieniu cech charakterystycznych polityki życia i polityki tożsamości czas przyjrzeć się społecznej funkcji, jaką pełni bohater literacki, a także postarać się dostrzec pewne wspólne cechy bohaterów analizowanych dzieł.

\footnotetext{
K. Wilkoszewska, Wariacje na postmodernizm, Kraków 2008, s. 69.

Z. Bauman, Tożsamość. Rozmowy z Benedetto Vecchim, Gdańsk 2007, s. 47.

M. Jacyno, Kultura indywidualizmu, Warszawa 2007, s. 20.
} 


\section{Społeczny wzór bohatera współczesnej literatury polskiej}

Nie ma nic nowatorskiego w stwierdzeniu, że literatura eksponuje określone cechy bohaterów, które odzwierciedlają założenia programów ideowych poszczególnych epok historyczno-literackich. W czasach średniowiecza hołdowała ona tradycji rycerskiej, natomiast bohater pozytywistyczny to przede wszystkim żarliwy społecznik. Kreacje literackie wpływały na rozumienie wzorców osobowych, kulturowych ideałów osobowości. Jak zauważył Stefan Czarnowski, bohater uosabia podstawową wartość społeczną, swoją postawą manifestuje ideę, wokół której zbiorowość organizuje życie. „Dzięki bohaterowi grupa utwierdza się jako zbiorowość ludzka, a jednocześnie bohater wyobraża prawa grupy do tego, w czym upatruje ona rękojmię swej trwałości"10. Z twierdzenia takiego można wysunać wniosek o swoistym zapotrzebowaniu społeczeństwa na określony typ bohatera i spontanicznej kreacji znanej postaci według określonego wzorca, schematu.

Pomimo licznych rozbieżności w pojmowaniu autorytetu, można by pokusić się o zsyntetyzowanie jednego uniwersalnego wzorca bohatera literackiego na miarę czasów rozpasanego kapitalizmu, czasów nieustającego karnawału, w których, jak sądzi wielu badaczy i publicystów, nie ma miejsca na żaden program ideowy, ponieważ „wolność w naszych czasach zaczęła oznaczać intelektualną pustkę ludzi młodych, którzy nie chcą uczestniczyć w żadnym dyskursie - społecznym, politycznym czy jakimkolwiek innym"11.

Według Romana Pawłowskiego we współczesnym dramacie polskim mamy do czynienia z trzema kategoriami bohaterów:

œ młodymi ludźmi sukcesu;

« generacją trzydziestolatków, którzy próbują zadebiutować w dorosłym życiu;

๙ ludźmi marginesu ${ }^{12}$.

Podobnego podziału typów bohaterów dokonuje Łukasz Drewniak. Według niego możemy dziś wyróżnić:

๙ władców Matrixa ${ }^{13}$, czyli wszystkich tych, których można by określić mianem decydentów;

» funkcjonariuszy - ludzi starających się odnaleźć w kapitalistycznej rzeczywistości;

10 S. Czarnowski, Kult bohaterów i jego społeczne podłoże, Warszawa 1956, s. 234.

11 K. Wandachowicz, Generacja Nic, „Gazeta Wyborcza” 2002, nr 207, s. 12.

12 Zob. R. Pawłowski, Wstęp, w: Pokolenie porno..., s. 7.

13 Pojęcie to według Drewniaka należy rozumieć jako „system opresji obyczajowoekonomiczno-ideologicznej w nowej kapitalistycznej Polsce". 
« kolaborantów i Wallenrodów, czyli tych, którzy w jakiś sposób próbują się tej rzeczywistości przeciwstawić;

« więźniów Matrixa - biernych obywateli ${ }^{14}$.

Warto zauważyć, że te typy bohaterów współczesnej literatury polskiej, które określone zostały jako władcy i funkcjonariusze Matrixa, zasadniczo wpisują się w zaprezentowaną przez Aldonę Jawłowską typologię strategii tożsamościowych proponowanych przez kulturę popularną. Są to:

« „samookreślenie, a zarazem udział w grze zainscenizowanej różnicy dzięki kupowaniu przedmiotów i usług [...];

$\diamond$ konstruowanie siebie poprzez manipulowanie własnym ciałem;

« «składanie» siebie z różnych cech i wzorów zachowań «bohaterów» kultury popularnej"15.

Prezentowana przez Jawłowską klasyfikacja możliwa jest do przyjęcia jako wyczerpująca wówczas, gdy alternatywa dotycząca cielesności nie będzie rozumiana w sposób wąski. Należy przyjąć w tym względzie raczej stanowisko Giddensa, który pisze: „Można wyróżnić kilka aspektów cielesności o szczególnym znaczeniu dla «ja» i tożsamości jednostki. Wygląd ciała obejmuje wszystkie cechy zewnętrzne, w tym strój i ozdoby, które są dla danej jednostki i innych osób widoczne i stanowią zazwyczaj wskazówki do interpretacji jej zachowań. Sposób bycia decyduje o tym, jaki użytek robi jednostka $\mathrm{z}$ wyglądu w typowych codziennych sytuacjach. [...] Zmysłowość ciała odnosi się do sposobu przyjmowania przyjemności i bólu. Wreszcie ciało jest poddawane rozmaitym reżimom" ${ }^{\prime \prime}$.

To, co wydaje się wspólne tak różnym typom bohaterów (nie wliczając pasywnych uczestników funkcjonującego systemu), to pewna skłonność do szeroko rozumianego dziwactwa, różnych rodzajów dewiacji, co czyni ich bohaterami wyrazistymi, czasami wręcz przerysowanymi. Jacek Hugo-Bader stwierdza: „Wydaje mi się, że podstawowym zadaniem bohatera, oczekiwanym społecznie jest to, aby był wyrazisty. Swego czasu napisałem tekst o młodych «samoobrońcach», młodzieży z Samoobrony. Zachwycali się tym, że ich przywódca - Lepper - jest wyrazisty"17. Współczesna literatura polska pełna jest takich postaci, to wręcz swoista galeria osobliwości.

Zob. Ł. Drewniak, Polski Matrix, „Dialog” 2006, nr 4, s. 12-14.

15 A. Jawłowska, Tożsamość na sprzedaż, w: Wokół problemów tożsamości, red. A. Jawłowska, Warszawa 2001, s. 72.

16 A. Giddens, dz. cyt., s. 137.

${ }^{17}$ A. Fieducik, Bohater naszych czasów, „Merkuriusz Uniwersytecki” 2005, nr 12; [http:// merkuriusz.id.uw.edu.pl/numer_12/opinie/Bohater_naszych_czasów,346.html; dostęp: 16.02. 2009]. 
Kiedyś na jarmarkach „prezentowano siłaczy łamiących podkowy, żonglerkę karłów, kobiety z brodą czy fakirów chodzących po rozpalonym żelazie. Erupcję tego typu atrakcji obserwowano zwłaszcza podczas karnawału, który - jak pisał Michaił Bachtin, rosyjski filozof kultury - służył przekraczaniu wszelkich tabu"18. Taką samą rolę spełniają bohaterowie współczesnej literatury. Co więcej, my sami jesteśmy tymi bohaterami, jesteśmy uczestnikami nieustannego karnawału ponowoczesnej hiperrzeczywistości. Jesteśmy jednak bohaterami zdeaktualizowanymi, pozostającymi zawsze o pół kroku za bohaterami literatury. Dlatego mogą się oni nam wydawać postaciami ubarwionymi, trochę nierzeczywistymi.

To jednak mylne wrażenie. Nierzeczywistość postaci literackich polega na tym, że najczęściej ich portret nie jest całościowy. Skupia się on na tych elementach, które ważne są z punktu widzenia fabuły lub czynią te postaci wyjątkowymi. Są to swego rodzaju typy idealne, wszak nie można oczekiwać, że w takim kształcie mogłyby one istnieć w rzeczywistości. Nie oznacza to jednak, że są nierealni, wymyśleni, bowiem najczęściej bohaterowie współczesnej literatury polskiej bazują na swoich odpowiednikach zaczerpniętych z rzeczywistości właśnie. Nie znaczy to również, że elementów wyjątkowości, rozumianej jako posiadanie pewnych cech charakterystycznych dla którejś z kategorii bohaterów literackich przedstawionych wyżej, nie możemy odnaleźć w sobie. Są one tylko bardziej rozmyte. Stąd, wszyscy jesteśmy ,jednocześnie aktorami i widzami. A ponieważ odświętny śmiech karnawału jest skierowany również przeciwko tym, którzy się śmieją, ludzie uczestniczący w karnawale są zarazem podmiotami i przedmiotami śmiechu" ${ }^{19}$. Taka perspektywa jest dla nas jednak trudna do przyjęcia. Bohater współczesnej literatury wydaje nam się inkarnacją cech, do których najzwyczajniej nie chcielibyśmy się przyznać, które chcielibyśmy wyprzeć, udając, że jesteśmy tylko odbiorcami bez wpływu na to, co dzieje się na kartkach książek czy na celuloidowej taśmie.

Wspólną kategorią wyżej wymienionego przekroju typów bohaterów literackich byłaby zatem kategoria freaka, rozumianego właśnie jako dziwaka, dziwoląga, maniaka, wybryku natury, którego zachowanie stanowi wynik różnych strategii radzenia sobie z lękiem wywoływanym życiem w ponowoczesnej rzeczywistości. Freak nie jest bynajmniej rozumiany przeze mnie w sposób pejoratywny. Przyjmuję za Robertem Bogdanem, że freak to „nastrój, zestaw praktyk, sposób myślenia i prezentowania się ludzi. To nakaz

18 M. Cieślik, Nieustraszeni pożeracze robali, „Wprost” 2004, nr 42, s. 64-65.

19 J. Lechte, Panorama wspótczesnej myśli humanistycznej, Warszawa 1999, s. 25. 
tradycji, spektakl stylizowanej prezentacji”20 I choć przyjmuje się często, że bycie freakiem nierozerwalnie łączy się z jakimś rodzajem cielesnych albo mentalnych zaburzeń, to wydaje się, że kategorię tę powinno stosować się także, a może przede wszystkim, do niekonwencjonalnych strategii autoekspresji.

Mamy tu zatem do czynienia $\mathrm{z}$ bohaterem o mniej lub bardziej neurotycznej osobowości, którego udziałem „stają się nie tylko lęki wspólne wszystkim członkom danej kultury, ale także - wynikające z jego indywidualnych warunków życiowych, choć splecione z warunkami ogólnymi - lęki różniące się pod względem ilościowym lub jakościowym od specyficznych lęków właściwych danemu wzorcowi kulturowemu"21. Taka kondycja bohatera literackiego wynika właśnie z próby ukształtowania własnej tożsamości, która czasami może zakończyć się porażką.

\section{W poszukiwaniu freaka}

Jak zostało wspomniane wyżej, mamy obecnie do czynienia z czasami wszechogarniającej zabawy, z nieustającymi bachanaliami, z okresem indywidualizmu, który jak najbardziej sprzyja emergencji jednostek dziwnych. Rozwój, czy ogólniej, idea postępu, miały prowadzić do ułatwienia życia, tymczasem utrudniają je nawet $\mathrm{w}$ tak podstawowych aspektach jak komunikacja międzyludzka. Nie chodzi tu oczywiście o mnogość sposobów komunikowania się ludzi, ale o ich jakość. Juliet Schor wskazuje, że u podstaw takiego stanu rzeczy leży brak spontanicznych kontaktów z drugim człowiekiem od najmłodszych lat. Dziś grupa rówieśnicza nie jest już grupą odniesienia. Tę rolę pełni obecnie telewizja, dzięki której większość z nas żywi nierealistyczne oczekiwania w stosunku do życia ${ }^{22}$.

Skóra, bohater Podróży do wnętrza pokoju, dramatu Michała Walczaka, mimo usilnych starań nie jest w stanie rozpocząć samodzielnego życia, więc zamyka się w wynajętym mieszkaniu niczym japońscy hikikomori, młodzi ludzie, którzy przez długie lata pozostają we własnych pokojach, ograniczając wszelkie kontakty do najbliższej rodziny. Mężczyzna żali się rodzicom: „Mamotato, jest mi tak przykro, zawsze chcieliście, żebym wyrósł na kogoś tam, na zewnątrz... A ja jakoś tak wrosłem, wrosłem do wewnątrz, i mi to wszystko się jakoś tak dzieje, mamotato, jakoś tak nierealistycznie, ja nie po-

R. Bogdan, Freak Show: Presenting Human Oddities for Amusement and Profit, Chicago 1990, s. 3.

K. Horney, Neurotyczna osobowość naszych czasów, Warszawa 1982, s. 34.

22 Zob. J. Schor, The Overspent American: Upscaling, Downshifting and the New Consumer, New York 1998. 
trafię normalnie rozmawiać, śmiać się, być naiwnym, zewnętrznym stworzeniem. Przepraszam, mamotato" 23 .

Skóra wydaje się być idealnym przykładem i ucieleśnieniem konsekwencji, do jakich może prowadzić ponowoczesny kryzys znaczeń. „W jednostkowej świadomości objawia się on psychologiczną anomią, jednostkowym doświadczeniem duchowej bezdomności (Camus), brakiem znaczenia lub mówiąc metaforycznie płynięciem bez instytucjonalnej kotwicy dającej poczucie zależności i wiary" ${ }^{24}$. Skóra pozostaje bezsilny wobec niemożliwego do ogarnięcia „zewnętrza”. Jest ono bowiem pozbawione centrum, wokół którego można byłoby konstruować spójną i trwałą tożsamość oraz indywidualną wizję świata.

Ponowoczesny brak centrum, w sposób symboliczny ucieleśnia Internet, którego strukturę można oddać za pomocą teoretyzowanej przez Deleuze'a i Guattariego metafory rizomu ${ }^{25}$. Rozwój tego medium sprzyjać może zanikowi spontanicznych relacji międzyludzkich, co z kolei objawia się albo próbą wycofania się, ucieczki, jak ma to miejsce w przypadku Skóry czy Karoliny z Absyntu Magdaleny Fertacz, albo coraz większym uzależnianiem się od świata materialnego.

„Dzisiejsza rzeczywistość zdominowana przez technikę i przemysł, pośpiech i zysk, prowadzi do rozwoju dóbr materialnych, pomijając to, co najistotniejsze - rozwój człowieka. Owa dysharmonia w relacji człowiek - rzeczywistość sprawia, że przestaje on być panem postępu, ale coraz bardziej jest jego ofiarą. Mechanizacja wymyka się spod jego kontroli. Ten proces uniezależnienia się wytworów od twórcy powoduje regres człowieka - ponowne uzależnienie się od świata materialnego. Na skutek tego ludzie odczuwają obcość nie tylko w stosunku do tego, co wytworzyli, ale także wobec naturalnego środowiska"26.

Tożsamość bohatera staje się wyjątkowo płynna. Izabela Kowalczyk pisze: „Nasza tożsamość rozpływa się dzisiaj w cyberprzestrzeni, staje się nieokreślona, zmienna. Nie potrzebuje ciała lub raczej konstruuje je według

\footnotetext{
M. Walczak, Podróż do wnętrza pokoju, w: Pokolenie porno..., s. 447-448.

B. Mikołajewska, Zjawisko wspólnoty, New Haven 1999, s. 238.

Kategoria „rizomu” zaczerpnięta jest z rozważań Gillesa Deleuze'a i Felixa Guattariego i powinna być rozumiana jako „kłącze”, które w metaforyczny sposób odnosi się do przemian, jakie zachodzą w pojmowaniu pisma, autorstwa, czy książki. „Kłącze” stanowi również model opisowy świata ponowoczesnego. Zob. G. Deleuze, F. Guattari, A Thousand Plateaus: Capitalism and Schizophrenia, London-New York 2004.

26 S. Bielawska, Kondycja człowieka w filmach Michelangelo Antonioniego, Kraków 2002, s. 89.
} 
własnych potrzeb, wciąż na nowo, wciąż inaczej”"27. Stąd, jak najbardziej zrozumiała jest strategia, jaką przyjmuje bohater dramatu Uśmiech grejpruta Jana Klaty:

@ Cotam robisz?

\$Czatuję, szaleję na listach dyskusyjnych, takie tam. Teraz właśnie ostro flir-

tuję z Gejzerem.

@ Z Gejzerem? Zmieniteś orientację?

\$Zmienilem płeć. W sieci jestem bardzo atrakcyjna szatynka. 90-60-90. Osiemnastka o wydatnych ustach. Czasem lubię zamacić w głowach pryszczatym nastolatkom. Gówniarze lubieżnie gapią się w ekran, ślina kapie na klawiaturę, a rodzice cieszą się, że pociecha rozwija swój intelekt ${ }^{28}$.

Te zagrożenia dostrzegane są przez współczesnych twórców, którzy wskazują na brak wartości, a nawet dokonują swoistego przewartościowania rzeczywistości pełnej obłudy i hipokryzji. W dramacie Klaty występuje „postać określona symbolem AND, artysta multimedialny, którego największym osiągnięciem jest zrobienie kupy w pawilonie polskim na biennale w Wenecji. Artysta tłumaczy, że chciał w ten sposób «nasrać na całe postkapitalistyczne społeczeństwo», co nie przeszkodziło mu jednak w sprzedaniu «rzeźby» za ciężkie pieniądze. AND jest tu nie tylko reprezentantem szokującego nurtu we współczesnej sztuce, który narusza społeczne i religijne tabu, ale przede wszystkim zręcznym graczem na rynku. Chcąc podbić cenę swoich dzieł, finguje własną śmierć, wie doskonale, że dobry artysta, to martwy artysta"29.

AND pragnie dołączyć do szeregu popkulturowych artystów, takich jak Jim Morrison czy Kurt Cobain, którzy „żyją” w dużej mierze dzięki własnej śmierci. Nie przeszkadza mu nawet, że trywializacja wszelkiej autentyczności czyni z tych postaci nic nieznaczące archetypy postaw buntowniczych. Wartości ideowe stwarzające poczucie więzi zostały wyparte współcześnie przez logikę wolnego rynku, która przyczynia się do schlebiania coraz to niższym gustom, do zapierania się samego siebie.

Stąd, pojawiające się, nie tylko w dramacie Klaty, ekskrementy. Wydają się one najlepszym sposobem na naruszenie tabu. Jedna z bohaterek Wojny polsko ruskiej pod flaga biało-czerwona Doroty Masłowskiej niemal przez połowę opowiedzianej w książce historii nieustannie wymiotuje, w Nie moim życiu Jerzego Nasierowskiego natomiast, znajdujemy opis starszej kobiety, która

27 I. Kowalczyk, Karmieni własnym lękiem i fantazja - estetyka subwersji i przemocy we współczesnej muzyce rockowej, w: Między dusza a ciałem, red. W. J. Burszta, M. Rychlewski, Warszawa 2003, s. 208-209.

28 J. Klata, Uśmiech grejpruta, w: Pokolenie porno..., s. 120.

29 R. Pawłowski, dz. cyt., s. 13. 
„bezwiednie” wydala kał. Odwołując się jeszcze raz do teorii karnawału Bachtina, należy zauważyć, iż „zdegradowanie, poniżenie, ciało i wszystkie jego funkcje - a w szczególności defekacja, oddawanie moczu i spółkowanie są integralną częścią ambiwalentnego doświadczenia karnawału"30. Ciało wydaje się być dziś czymś, co z pewnością nie stanowi już wartości absolutnej, co nie stanowi żadnego ograniczenia dla wyobraźni, czasami nawet wydaje się być czymś zupełnie zbędnym. Dychotomiczny podział na ciało i duszę charakterystyczny dla zachodniego kręgu cywilizacyjnego, w czasach, kiedy „tworzy się odrębna sfera wyobraźni ludzkiej, wypełniona wyimaginowanymi światami «niby-realności»" ${ }^{11}$, doprowadził ostatecznie do obniżenia wartości ciała jako takiego.

Działanie bohatera dramatu Klaty to również obnażenie zasad funkcjonowania wolnego rynku. Tutaj spotykają się trzy wymienione przez Pawłowskiego kategorie bohaterów. „Normalne” funkcjonowanie staje się wręcz niemożliwe, dlatego kapitalizm to już nie ustrój, który przyniósł nam wolność, ale, jak czytamy na tylnej okładce Nie mojego życia Nasierowskiego, rzeczywistość, „w której rozmaite indywidua, skazane przez dokonaną przemianę ustrojową na kaleką, upokarzającą wegetację i codzienne borykanie się z przeciwnościami, próbują jednak w tej rzeczywistości funkcjonować i zachowując resztki człowieczeństwa - nie dać się zepchnąć na dno"32.

Wolność, o którą kiedyś toczyła się walka, jest dziś chroniona przez funkcjonariuszy policji, którzy u Masłowskiej są ucieleśnieniem chorego systemu: „Samochodzik podjeżdża. Szybka uchyla się. Palant w czarnym kombinezonie przeciwpożarowym o twarzy seryjnego mordercy z dożywociem i karą śmierci na karku, wozi tym wózkiem swą państwową, czarną dupę jakby co najmniej jechał na wakacje, ramię wystawione, pełen luz, może jeszcze drink i rozkładane łóżko"33.

Dla Przemysława Wojcieszka natomiast, kapitalistyczna degrengolada zauważalna jest najbardziej na przykładzie współczesnych mediów, które krytykuje on w swym dramacie Zabij ich wszystkich. Bohaterowie śledzący zamieszki będące wynikiem przypadkowej śmierci kibica w Słupsku w 1997 roku komentują:

GRZEGORZ: Pedały. Matkojebcy. Skurwiel wyglada na takiego, co pociagnałby swojej starej. Problem tylko w tym, że kurwa nie ma kutasa.

EWA: Zmień kanat.

\footnotetext{
Jo Lechte, dz. cyt., s. 25.

W. Burszta, Antropologia kultury, Poznań 1998, s. 161.

J. Nasierowski, Nie moje życie.

D. Masłowska, Wojna polsko-ruska pod flaga biało-czerwona, s. 160.
} 
GRZEGORZ: Daj spokój. Ten program ma bardzo wysoką oglądalność. Ludzie go uwielbiaja.

MAREK: Może puszczą coś o zamieszkach.

EWA: Chyba w radzie nadzorczej ich pierdolonej korporacji.

GRZEGORZ (siegga do pokrętta i wybiera inny program. Betkot.)

EWA: O kurwa.

GRZEGORZ: Jak będziesz ciagle narzekać, nigdy niczego nie polubisz.

EWA: Mam to polubić? Z gównem należy walczyć.

GRZEGORZ: Walcz. Tylko mi nie rozpierdol telewizora ${ }^{34}$.

$\mathrm{Z}$ dramatu tego dowiemy się również, kogo obwinia się za taki stan rzeczy. W głównej mierze obciąża się elity polityczne, a zwłaszcza tych, którzy w latach osiemdziesiątych stanowili polityczną opozycję: „Niedawno w naszej szkole pojawiła się taka świnia. Pierdolony bojownik podziemia. Była jakaś rocznica i ktoś go zaprosił. Nie wiem kto. Pewnie jakaś kurwa z dyrekcji. Nie wiem czy pierdoli ją, jej córkę, czy może pierdoli jej męża. Skurwysyn w garniturze od Diora. Stanął na środku i zaczął ględzić - jak tracił wzrok przy powielaczu, więc może, kurwa, bylibyśmy mu choć trochę wdzięczni. Stał tam na środku - śmierdząca fabryka gówna - i żebrał o naszą litość"35.

Czy bohatera współczesnej literatury polskiej stać tylko na taką formę wyrażenia swojego sprzeciwu wobec rzeczywistości? Czy Skóra jest zdolny do opuszczenia pokoju i rzucenia światu wyzwania, oskarżenia go o to, co z nim, młodym mężczyzną ten świat zdążył zrobić? Trudno podejrzewać freaków o chęć jakichś działań zbiorowych, kontrkulturowej kontestacji, która miałyby służyć artykulacji ich niezadowolenia ze świata. Być może jedyną formą buntu, na jaką stać obecnie młodych ludzi, jest jego bardzo zindywidualizowana wersja, jaką proponuje John Fiske, zdaniem którego „uczestnicząc w jakimkolwiek zjawisku popkulturowym, czy będą to zakupy w hipermarkecie, czy oglądanie reklam telewizyjnych, mamy prawo do własnej interpretacji tego, czego doświadczamy. Możemy w dowolny sposób odbierać, a nawet zupełnie przekręcać intencje tych, którzy pop-kulturę tworzą"36.

Tym, dla których taka perspektywa wydaje się nie do przyjęcia, pozostaje ucieczka od rzeczywistości. Max, bohater Masali Maxa Cegielskiego, ucieka najpierw za pomocą narkotyków od siebie, później ucieka od polskich realiów, a celem tej ucieczki są Indie. Kieruje się on po trochu wskazaniami

34 P. Wojcieszek, Zabij ich wszystkich, w: Pokolenie porno..., s. 472-473.

35 Tamże, s. 474.

${ }^{36}$ K. Michalska, Ruch oporu w pop-kulturze. Teorie Johna Fiske'a, „Magazyn Obywatel” 2001, nr 4, s. 52. 
zawartymi w Podróży na Wschód Hermanna Hessego ${ }^{37}$, a częściowo czyni z samej podróży kategorię filozoficzną, jak miało to miejsce w przypadku nomadów amerykańskiej literatury, Jacka Kerouaca i Williama Burroughsa. Cegielski, nie jako bohater książki, ale jako jej autor, najlepiej ucieleśnia wpływ kapitalistycznej rzeczywistości na młodego człowieka. Dziennikarz i didżej radiowy, były prezenter telewizyjny zaczyna czuć, że nie pasuje do wciąż przyśpieszającego świata. Zrobienie dobrego wywiadu do swojego programu telewizyjnego często odreagowywał, zażywając narkotyki. Z biegiem czasu, z kanału telewizyjnego trafił prosto do ośrodka dla uzależnionych.

Podsumowując, freak to bohater pozbawiony poczucia bezpieczeństwa. „Im bardziej lęk jest dokuczliwy, tym intensywniejsze muszą być środki obronne. W naszej kulturze spotykamy cztery główne sposoby obrony przed lękiem podstawowym, i są to: miłość, uległość, władza i wycofanie się"38. We współczesnej literaturze polskiej bez większych problemów odnaleźć można postaci, które idealnie wpasowują się w którąś z tych strategii. Zdolności adaptacyjne późnej nowoczesności są niestety tak wielkie, że strategii tych nie odczytujemy nawet jako działań obronnych.

\section{Podsumowanie}

Podejmowana przez bohatera współczesnej literatury polskiej próba określenia swojego miejsca w świecie jest w epoce późnej nowoczesności jak najbardziej zrozumiała. W momencie, w którym kultura funkcjonuje bez jasno wytyczonego centrum aksjonormatywnego, jednostka zaczyna sama dla siebie stanowić ostateczne kryterium wartościowania, zaczyna podnosić własne indywidualne rozterki do rangi problemów o charakterze politycznym. I choć sfera działań politycznych, w myśl tradycyjnych koncepcji, odnosiła się zawsze do działań na rzecz dobra wspólnego, tudzież przeciwko innej grupie, to obecnie elementem konstytuującym polityczność stają się wszelkie obiekty, wszelcy aktorzy, także nie-ludzcy. To, co polityczne ujawnia się również $\mathrm{w}$ relacji do przedmiotów, które pośredniczą w kontaktach interpersonalnych. Taka skrajnie zindywidualizowana wizja polityki wydawać się może zaprzeczeniem schematu myślowego, który zawdzięczamy Arystotelesowi, a mianowicie koncepcji człowieka jako zoon politikon. Dlatego polityka życia ma swoich gorących oponentów. Zygmunt Bauman pisze: „Kiedy polityka publiczna zrzeka się swoich funkcji na rzecz polityki życia, problemy, których doświadczają jednostki de iure, usiłując się stać jednost-

37 Zob. H. Hesse, Podróż na Wschód, Warszawa 2004.

38 K. Horney, dz. cyt., s. 76. 
kami de facto, nie sumują się i nie kumulują. Ogołaca to sferę publiczną ze wszelkiej treści, czyniąc z niej podium, na którym wystawia się na widok publiczny prywatne troski" 39 .

Kolejny raz pojawiają się zatem sentymenty dotyczące sfery publicznej, która rzekomo zanika. W moim przekonaniu, wcale nie mamy do czynienia z degradacją tego, co polityczne. Wprost przeciwnie, polityka życia oraz polityka tożsamości doprowadziły do niebywałej polityzacji życia jako takiego. Problemem może być oczywiście jakość tematów, które są podejmowane w ramach tych koncepcji politycznych. Stanisław Łojek, dokonując omówienia teorii Leo Straussa, pisze: „Niebezpieczeństwo polega [...] na utracie powagi życia ludzkiego; nie oznacza to jednak, że to, co polityczne, jako «zawsze obecna możliwość» może zostać zniesione czy zanegowane. Liberalizm jest zatem groźny nie dlatego, że może osiągnąć swój cel - sytuacja, w której ludzie się nie spierają, jest zasadniczo niemożliwa - ale dlatego, że oddziałując na jakość tego, o co ludzie się spierają, przyczynia się do osłabienia powagi życia"40.

Równie ostre zarzuty formułowane są pod adresem polityki tożsamości. Agnieszka Kołakowska pisze, że pojęcie tożsamości grupowej jest przejawem totalitarnej mentalności. Błędem jest: „[...] przekonanie, że określa nas w sposób podstawowy przynależność do jakiejś grupy - seksualnej, społecznej, religijnej lub etnicznej. Doprowadziło to do „ugettowienia” pewnych grup etnicznych w imię ich wolności i godności. Pogląd, iż to, co robimy i to, kim jesteśmy, zależy od naszej płci, rasy, orientacji seksualnej lub przynależności do danej grupy etnicznej, jest nie tylko absurdalny i wyjątkowo obraźliwy, lecz nadto niszczy tę właśnie wizję społecznej harmonii i wspólnego dobra, która rzekomo leży u podstaw ideologii politycznej poprawności" ${ }^{\prime 4}$.

Trudno tej wypowiedzi odmówić racji. Przyglądając się bowiem kolejom losu, jaki spotkał ruch kontrkulturowy, następnie kulturę alternatywną i powstałe na jej podstawie nowe ruchy społeczne, trudno nie dojść do wniosku, że, choć wyrosłe na wspólnym gruncie, ruchy te często bronią odmiennych, sprzecznych ze sobą interesów. Kontrargument, dla sformułowanego przez Kołakowską zarzutu, może stanowić koncepcja radykalnej demokracji Chantal Mouffe i Ernesto Laclau, której fundamentem ma być respektowanie odmienności, różnicy, i w ramach której podstawową wartością ma być dialog. Koncepcja taka pozwala zatem na kształtowanie tożsamości poprzez

39 Z. Bauman, Płynna nowoczesność, Kraków 2006, s. 81.

40 S. Łojek, Hegel i Nietzsche wobec problemu polityczności, Wrocław 2002, s. 145.

41 A. Kołakowska, Polityczna poprawność a mentalność totalitarna, w: Totalitaryzm a zachodnia tradycja, red. M. Kuniński, Kraków 2006, s. 229. 
partycypację w działaniach ruchu społecznego z jednoczesnym poszanowaniem odmienności światopoglądowej innych ruchów.

Wszystkie te napięcia mają swoje odzwierciedlenie w postawie bohatera współczesnej literatury polskiej. Freak jest dziwakiem, który usiłuje wyznaczyć granice swojej egzystencji w świecie. $Z$ jego punktu widzenia wystarczające są takie granice, które porządkują jego własny Weltanschauung. Oczywiście, granice te są niezwykle zmienne, płynne, efemeryczne, jednak brak jakichkolwiek cezur może owocować całkowitym wycofaniem się z życia społecznego. Najważniejszy zatem w czasach kultury indywidualizmu staje się osobisty spektakl autoekspresji, który jako świadomy projekt pozwala na doświadczanie własnego istnienia w sposób głębszy, bardziej wyraźny. Jak zauważa Rüdiger Bubner: „W epoce mediów triumfuje skłonność do przekształcania wszelkiej treści w obrazy przed szeroką publicznością i zarazem rekrutowania publiczności w charakterze współautora. Działanie społeczne staje się działaniem demonstrowanym, podmioty stylizują swoje pragnienia i zainteresowania na pozy"42.

Nieustanna zmienność, która objawiać się może choćby na poziomie ubioru, a także negacja tradycyjnych zasad społeczno-politycznych jako niemających nic wspólnego z osobistym doświadczeniem życiowym bohatera, stają się głównymi cechami charakteryzującymi freaka.

Dlatego też, freak raczej wpisuje się w logikę polityki życia niż polityki tożsamości. I choć można by doszukać się elementów niepotwierdzających takiej konstatacji, jak choćby: silna identyfikacja z płcią wśród przeważającej części bohaterów; to na główny plan wysuwa się jednak wewnętrzny imperatyw kształtowania swojej biografii. Indywidualizm, który objawia się w przypadku bohatera współczesnej literatury niemalże pod postacią osobowości narcystycznej, dewaluuje wszelkie, nawet najdrobniejsze, przejawy działań zbiorowych.

42 R. Bubner, Doświadczenie estetyczne, Warszawa 2005, s. 178. 


\section{Abstract}

The article is an attempt to find a model of the modern Polish literary character as well as to define his or her political attitude in the light of such socio-political theories like identity politics or the politics of life. As a dominant cultural attitude, ultraindividualism is nowadays conducive to emerging of weird individuals, which I propose to call by a term "freak". It has to be stressed that a "freak" is not understood in a pejorative way. His or her constitutive element is a specific spectacle of autopresentation, justified by ostentatious character of any social activity. In the frameworks of widely understood eccentricity we can encounter a variety of identity strategies, which in the times of postmodernity are an answer to all the individual and group anxieties. The demand for a literary character whose private sphere would be presented in a very detailed way results from the condition of contemporary societies. To accuse literary characters of political passivity is not to notice the turn that took place in the sphere of political activity and the political itself. On the other hand, the politics of life allows of theorizing the eccentricity of the modern Polish literary character in political terms. 